\title{
World Covid-19 Vaccine Names Classification Using Neural Network Method
}

\author{
Kristiawan Nugroho \\ AMIK Jakarta Teknologi Cipta \\ J1. Kelud Raya No 19 Semarang Indonesia \\ kristiawan1979@gmail.com
}

\begin{abstract}
The Covid-19 pandemic has occurred for a year on earth. Various attempts have been made to overcome this pandemic, especially in making various types of vaccines developed around the world. The level of vaccine effectiveness in dealing with Covid19 is one of the questions that is often asked by the public. This research is an attempt to classify the names of vaccines that have been used in various nations by using one of the robust machine learning methods, namely the Neural Network. The results showed that the Neural Network method provides the best accuracy, which is $99.9 \%$ higher than the Random Forest and Support Vector Machine (SVM) methods.
\end{abstract}

Keywords - Covid-19, Vaccines, Classify, Neural Network

\section{INTRODUCTION}

Covid-19 is a virus that has been attacking various nations around the world for one year. This virus was originally thought to have originated in Wuhan China and is believed to have started spreading throughout the world from the end of 2019 until now. Covid-19 or also known as SARS-CoV-2 is a type of RNA virus that is shaped like a crown when viewed on an electron microscope [3].

The Covid-19 pandemic has resulted in various kinds of losses felt by mankind, including the death of many people in the world, economic and social losses that have caused various nations to suffer. Various attempts have been made by scientists from various nations in the world to find and make vaccines that are expected to provide human immunity against the Covid-19 virus. The efforts of scientists around the world are starting to produce good news with the discovery of various types of variants of the name of the vaccine that have been produced. The various vaccines include Sinovac and Sinopharm, which are two types of vaccines produced in China (Ophinni et al., 2020), Pfizer-BioNTech from the United States [13], Johnson \& Johnson which are produced in the UK and various types. other vaccines.

Currently, the process of administering vaccines has been carried out by various countries in the world for their residents, especially those who receive top priority, namely health workers and elderly people. However, due to the large population of the world and the many variations in the names of vaccines given, it is difficult to classify the types of vaccines used around the world. This study uses a Machine Learning approach using the Neural Network method which is known as one of the best methods of classifying data.

Neural Network (NN) is a method that works like a human neural network in responding to activities in life. This method is used in various studies, including weather prediction [14] which produces a method accuracy rate of $72.97 \%$. $\mathrm{NN}$ is also used in predicting the price of salt commodities [5] which uses the Mean Absolute Percentage Error (MAPE) to measure forecasting. This study produces an MAPE level of 4,394\%.

The diagnosis of TB disease [2] also uses the $\mathrm{NN}$ approach which results in an accuracy rate of $89.89 \%$. In another study [12] using the $\mathrm{NN}$ method in predicting rice prices, this study in an accuracy rate of $88.14 \%$ and a low error rate of $11.86 \%$. In addition, the $\mathrm{NN}$ method is also widely used in the field of population [6], construction design [11] and export volume [14]. 
This study uses the NN method which processes the dataset of various vaccines throughout the world. Neural Network classifies the names of various types of vaccines given to the community and then their accuracy is tested to be compared with other methods such as SVM and Random Forest which are also robust methods in Machine Learning.

\section{METHOD}

The stages of the research carried out can be seen in Figure 1 as follows:

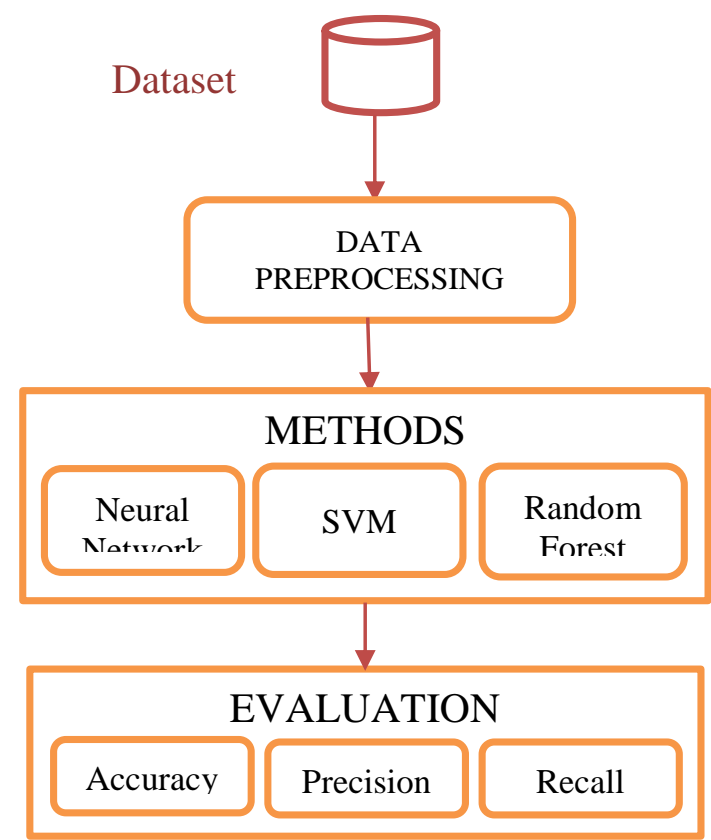

Figure 1. Research Methods

The research stage was carried out using a dataset taken from the website of the public dataset provider, Kaggle, which is a dataset named Country Vactination. The dataset is then processed with the Orange application, namely by conducting preprocessing. The next stage is the prediction process using three approaches, namely Neural Network, Naive Bayes and Random Forest. The final stage after classification is to conduct an evaluation to measure accuracy, precision and recall for each method that has been used.

Three methods were used in this study :

a. Neural Network

The NN method is one of the methods in Machine Learning that works like a human neural network. $\mathrm{NN}$ is an artificial intelligence system that functions as an information processor that has the same performance as a human neural network [4].

b. Support Vector Machine(SVM)

Like NN, SVM is one of the proven methods in Machine Learning. SVM is a promising statistical learning theory and provides better performance results compared to other methods because the kernel technique must map the original data from its original dimension to another dimension that is relatively higher [1]

c. Random Forest

Random Forest (RF) is also a method that has a good performance in Machine Learning. $\mathrm{RF}$ is a method that can improve the performance of accuracy results because generating child nodes for each node is done randomly [9].

Meanwhile, three ways to evaluate in this study use:

a. Accuracy

Accuracy is the closeness of the measurement results that have been made to the actual value in Machine Learning. Accuracy is the ability to move an object to make appropriate suggestions, so that the goal will be achieved properly.

b. Precision

Precision is one of the tools for measuring evaluation in Machine Learning. Precision is the level of consistency of the observations that have been determined in the magnitude of the difference from the resulting value. According to Mayadewi, precision is a match between requests for information and answers to requests [8].

c. Recall

Recall is a unit that is useful for measuring the ratio of the relevant items selected to the total number of relevant items available [8].

\section{RESULTS AND DISCUSSION}

Based on the results of research that has been carried out using the Orange application, 
which is one of the tools in data mining analysis that can evaluate and provide visualization [7]. This application was built using the python and $\mathrm{C}++$ programming languages, among others. The results of the research can be explained as follows:

\section{A. RESULT}

After carrying out the preprocessing process with the orange application, the vaccine administration dataset is then classified with several Machine Learning algorithm models, then the performance results are measured in the evaluation process as shown in Figure 2 as follows:

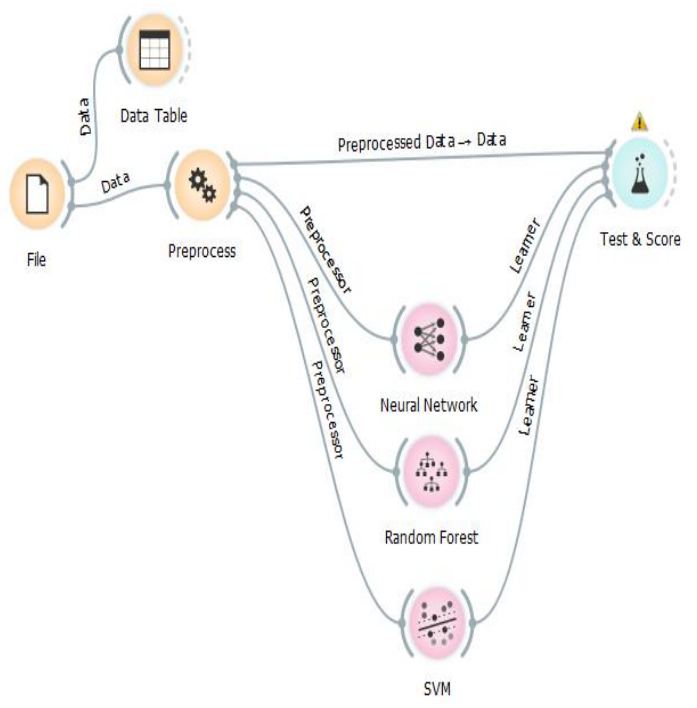

Figure 2. Orange Design

Figure 2 above shows the dataset which after preprocessing is classified by 3 methods, namely Neural Network, SVM and Random Forest, then the classification results are evaluated by the Test $\&$ Score model.

\section{B. DISCUSSION}

Based on the classification results that have been carried out by 3 methods, the results are as shown in table 1 as follows:

Table 1. The Classification of Vaccine

\begin{tabular}{|c|c|c|c|}
\hline Methods & Accuracy & Precision & Recall \\
\hline $\begin{array}{c}\text { Neural } \\
\text { Network } \\
\text { (NN) }\end{array}$ & $\mathbf{9 9 . 5 \%}$ & $\mathbf{9 9 . 5 \%}$ & $\mathbf{9 9 . 5 \%}$ \\
\hline $\begin{array}{c}\text { Support } \\
\text { Vector } \\
\text { Machine } \\
\text { (SVM) }\end{array}$ & $98.9 \%$ & $98.8 \%$ & $98.9 \%$ \\
\hline $\begin{array}{c}\text { Random } \\
\text { Forest }\end{array}$ & $98.8 \%$ & $98.8 \%$ & $98.8 \%$ \\
\hline
\end{tabular}

Looking at table 1 above, we can conclude that the Neural Network method has good performance in terms of accuracy, precision and recall compared to SVM and Random Forest.

\section{CONCLUSION}

Research on the classification of vaccine names around the world has been carried out. The process has succeeded in classifying vaccine names using various methods in Machine Learning, namely Neural Network, SVM and Random Forest. After analyzing and evaluating the Neural Network method, the highest accuracy, precision and recall rate is $99.5 \%$.

\section{REFERENCES}

[1] Adi, K. And Isnanto, R. R. (2016) 'Klasifikasi Citrasupport Vector Machine Untuk Jenis Daging Berdasarkan Tekstur Menggunakan Ekstraksi Ciri Gray Level CoOccurrence Matrices ( GLCM )', 01, Pp. 1-10. Doi: 10.21456/Vol6iss1pp1-10.

[2] Amrin, A. (2019) 'Diagnosis Of Tuberculosis By Artificial Neural Network Algorithm', Sinkron, 3(2), P. 223.

Doi:

10.33395/Sinkron.V3i2.10028.

[3] Di Gennaro, F. Et Al. (2020) 'Coronavirus Diseases (COVID-19) Current Status And Future Perspectives: A Narrative Review', International Journal Of Environmental Research And Public Health, 17(8). Doi: 10.3390/Ijerph17082690.

[4] Gernowo, R. And Surarso, B. (2016) 'Metode Jaringan Syaraf Tiruan Untuk Prediksi Performa Mahasiswa Pada Pembelajaran Berbasis Problem Based Learning ( PBL )', 01, Pp. 46-58. Doi: 10.21456/Vol6iss1pp46-58.

[5] Habibi, M. Y. And Riksakomara, E. (2017) 'Peramalan Harga Garam Konsumsi Menggunakan Artificial Neural Network FeedforwardBackpropagation (Studi Kasus: PT. Garam Mas, Rembang, Jawa Tengah)', Jurnal Teknik ITS, 6(2). Doi: 
10.12962/J23373539.V6i2.23200.

[6] Izati, A. (2019) 'Artificial Neural Network The Application Of Artificial Neural Network Method In Forecasting The Number Of Pregnant Woman Visits ( K4 )', Jurnal Biometrika Dan Kependudukan, (March 2019).

[7] Kodati, S. And Vivekanandam, R. (2018) 'Analysis Of Heart Disease Using In Data Mining', 18(1).

[8] Mayadewi, P. (2015) 'Prediksi Nilai Proyek Akhir Mahasiswa Menggunakan', Seminar Nasional Sistem Informasi Indonesia, (November), Pp. 2-3.

[9] Nugroho, Y. S. (2017) 'Sistem Klasifikasi Variabel Tingkat Penerimaan Konsumen Terhadap Mobil Menggunakan Metode Random Forest', Jurnal Teknik Elektro, 9(1).

[10] Ophinni, Y. Et Al. (2020) 'COVID-19 Vaccines: Current Status And Implication For Use In Indonesia', Acta Medica Indonesiana, 52(4), Pp. 388412.

[11] Prathama, A. Y. Et Al. (2017) 'Untuk Penentuan Prosentase Bobot Pekerjaan Pada Rumah Sakit Pratama', 7. Doi: 10.22146/Teknosains.30139.

[12] Putra, H. And Ulfa Walmi, N. (2020) 'Penerapan Prediksi Produksi Padi Menggunakan Artificial Neural Network Algoritma Backpropagation', Jurnal Nasional Teknologi Dan Sistem Informasi, 6(2), Pp. 100-107. Doi: 10.25077/Teknosi.V6i2.2020.100-107.

[13] Shimabukuro, T. And Nair, N. (2021) 'Allergic Reactions Including Anaphylaxis After Receipt Of The First Dose Of Pfizer-Biontech COVID-19 Vaccine', JAMA - Journal of The American Medical Association, 325(8), Pp. 780-781. Doi: 10.1001/Jama.2021.0600.

[14] Yuniarti, T. Et Al. (2017) 'Penggunaan Artificial Neural Network ( Ann ) Untuk Memodelkan Volume Ekspor Crude Palm Oil ( CPO )', pp. 247-255.
[15] Yunita (2015) 'Prediksi Cuaca Menggunakan Metode Neural Network', XVII(2), pp. 47-53. 